УДК 141.7

3. С. Вихованець, к. філос. н.

\title{
ФЕНОМЕН СОЦІАЛЬНОÏ ДІЇ В КОНСТРУКЦІЯХ ФІЛОСОФІї ТЕЇЗМУ
}

Актуальність теми дослідження. Еволюційний шлях перетворень запобігав руйнації традиційно прийнятих способів організації колективної взаємодії, тому безперечно актуальною залишається проблематика суспільно-історичної динаміки фоормування певного устрою соціального життя.

Постановка проблеми. Основу соціального порядку створює типологія соціальної дії, яка має історичний характер і проявляється в різних соціальних структурах. Звідси випливає ідея поєднання соціального та духовно-культурного проєктів формування життєдіяльності суспільства у фрілософрії теїзму, а процес їх реалізації забезпечує механізм концептуалізації цілісного людського буття та соціального порядку.

Аналіз останніх досліджень і публікацій. Джерелами нашої розвідки стали твори таких відомих мислителів як М. Вебер, Е. Дюркгейм, Н. Луман, Т. Парсонс та ін.

Виділення недосліджених частин загальної проблеми. Аналіз проблеми вирішення феномену формування ідеальної типології соціальної дії за допомогою духовно-практичного потенціалу фрілософьького теїзму здійснюється у науковій літературі вперше.

Постановка завдання. Дослідити феномен соціальної дії в конструкціях фрілософрії теїзму.

Виклад основного матеріалу. Вітчизняний культурний простір включає в себе складну конфрігурацію поєднання ціннісно-раціональних дій, чим саме забезпечує фрормування характерних рис національної традиції побудови соціальної форми життєдіяльності. Філософрський теїзм має величезне культурологічне та соціальне значення, адже завдяки дифреренційної сукупності своїх фоорм здійснює фуункцію посередника між релігійними засадами та соціокультурним середовищем.

Висновки. Філософрський теїзм завдяки можливостям фоормування ідеальної типології соціальної дії забезпечує процес поєднання духовного потениіалу християнської традиції та сучасної соціально-правової структури базових європейських цінностей з метою формування стабільних засад функиіонування соціального порядку.

Ключові слова: соціальна дія; суспільство; соціальна система; фрілософрський теїзм; соціальний порядок; цілісне людське буття; духовний потенціал; європейські цінності.

Z. S. Vykhovanets, Candidate of Philosophical Sciences

\section{PHENOMENON OF SOCIAL ACTION IN CONSTRUCTIONSOF PHILOSOPHY OF THEISM}

Urgency of the research. The evolutionary path of transformation prevented the destruction of traditionally accepted ways of organizing collective interaction, so the issue of socio-historical dynamics of the formation of a certain system of social life undoubtedly remains relevant.

Target setting. The basis of the social order is created by the typology of social action, which has a historical character and is manifested in various social structures. Hence the idea of combining social and spiritual-cultural projects of society formation in the philosophy of theism, and the process of their implementation provides a mechanism for conceptualizing holistic social order.

Actual scientific researches and issues analysis. The sources of our research were the works of such famous thinkers as M. Weber, J. Dewey, E. Durkheim, N. Luhmann, T. Parsons and others. Theoretical and methodological analysis of the concept "social activity - spirituality - culture" is presented in the works of such domestic scientists as A. Yermolenko, S. Krymskyi, M. Popovych and many others.

Uninvestigated parts of general matters defining. The analysis of the complex problem of solving the phenomenon of formation of the ideal typology of social action with the help of the spiritual and practical potential of philosophical theism is carried out in the scientific literature for the first time.

The research objective. To investigate the phenomenon of social action in the constructions of the philosophy of theism.

The statement of basic materials. The national cultural space includes a complex configuration of a combination of value-rational actions, which ensures the formation of the characteristic features of 
the national tradition of building a social form of life. Philosophical theism has a huge culturological and social significance, because due to the differential set of its forms it acts as a mediator between religious principles and socio-cultural environment.

Conclusions. The ideas of philosophical theism are always in the nature of philosophical conceptualization, which is carried out on the basis of a certain religious and cultural tradition and has a specific historical and semantic dimension. Philosophical theism, thanks to the possibilities of forming an ideal typology of social action, provides a process of unique combination of the spiritual potential of the Christian tradition and the modern socio-legal structure of basic European values to ensure fundamentally stable foundations of social order.

Keywords: social action, society; social system; philosophical theism; social order; integral human existence; spiritual potential; European values.

DOI: 10.25140/2412-1185-2019-2(14)-7-12

Актуальність теми дослідження. Принциповий перехід від тоталітарного державного контролю до демократичних правил організації суспільного життя, а також поступова заміна одного типу соціальної системи на іншу виключала збройно-насильницький спосіб революційних змін наприкінці XX - початку XXI ст. в Україні. Еволюційний шлях перетворень запобігав руйнації традиційно прийнятих способів організації колективної взаємодії та консолідації українського суспільства на основі тисячолітнього потенціалу духовних цінностей. «Структурні зміни здійснюються у відповідності з еволюціоністською моделлю. Кожна наступна фраза відрізняється наростаючою складністю, яка проявляється у збільшенні числа і різноманітності спеціалізованих одиниць внутрішньої системи. Це з необхідністю вимагає нових фрорм кооперації, координації та організації, тобто соціокультурна еволюція, як і еволюція організмів, рухається від простих форм до більш складних. Іншими словами, фрактором, який спрямовує еволюцію, є зростання здібностей до адаптації. Але це тільки загальна тенденція, яка не виключає відмінностей специфічних еволюційних траєкторій. Еволюція не $є$ однолінійною, вона багатогранна та на кожному новому рівні включає в себе достатньо широку різноманітність форм і типів» [1, с. 160-161], - тому потенціал духовних цінностей утворює свого роду просторово-часову основу, актуалізуючи завдяки наскрізним утворенням духу нові смислові звершення еволюційного процесу.

У свою чергу, категорія «філософрського теїзму» завжди носить характер фрілософрської концептуалізації, яка здійснюється на засадах певної релігійно-культурної традиції та має конкретний культурно-семантичний вимір. У нашому випадку, ми можемо стверджувати, що феномен соціальної дії в конструкціях фрілософрського теїзму уособлює собою унікальне поєднання ґрунтовних ідей християнської православної традиції та базових принципів європейської філософської думки. Європейська культурна традиція на будь-якому історичному етапі свого розвитку постійно ототожнювала релігію з теїзмом, визнаючи пізнавальні та нормативні можливості філософії. Результатом такого поєднання стає той фракт, що філософрський теїзм поступово набуває ознак легітимізації разом з процесом набуття християнською теологією наукового саморозуміння, тобто саме філософрія починає виконувати функцію наукової рефрлексії й саморефлексії у західній християнський теології.

Конституція людської особистості, яка формує типологію соціальної дії, складається з духа, самого життя та принципів особистості. Зазначені константи виконують особливу онтологічну функцію: дух уособлює собою найближчу мету екзистенційної самореалізації, а вітальний рівень тіла та «я» визначають спосіб буття духу. Структура такого життєвого простору несе в собі суспільно-історичний сенс, тому колективне «я» стає обов'язковою складовою для розуміння існування людини у різних історичних епохах і культурах. У цьому відношенні «суттєво важливі культурні зразки, тобто комплекси значення, вони можуть породжуватися та зберігатися у якості доступних ресурсів для дії в інших системах лише у тому випадку, якщо мають місце процеси дії, що спрямовані, головним чином, на створення чи збереження таких зразків» [2, с. 698], саме філософський теїзм завдяки своїм фрормам існування забезпечує відтворення базових цінностей культурно-релігійного характеру. Відповідно, безперечно актуальною залишається проблематика суспільно-історичної динаміки формування певного устрою соціального життя завдяки феномену ідеальної типології соціальної дії в конструктах фрілософрського теїзму. 
Постановка проблеми. Основу соціального порядку створює типологія соціальної дії, яка має історичний характер і проявляється в різних соціальних структурах. Звідси випливає ідея поєднання соціального та духовно-культурного проєктів формування життєдіяльності суспільства у фрілософії теїзму, а процес їх реалізації та спосіб органічного поєднання забезпечує механізм концептуалізації цілісного людського буття та соціального порядку.

Аналіз останніх досліджень і публікацій. Базовими джерелами нашої розвідки стали твори таких відомих мислителів як А. Бадю, М. Вебер, Ю. Габермас, Дж. Дьюї, Е. Дюркгейм, Н. Луман, Т. Парсонс, П. Рікер, А. Шопенгауер та багато інших, чиї роботи присвячені проблемам аналізу соціальної реальності та діяльності. Філософсько-епістемологічне обґрунтування теїзму ми знаходимо у працях дослідників різних історичних періодів, наприклад П. Ліницький вважав, що філософрія $€$ особливою формою самоусвідомлення людського духу, вінцем розвитку національної культури, тобто, зважаючи на те, які філософські традиції розвиваються в межах певної національної культури, можна судити про особливості світосприймання і світорозуміння певної нації, а саме такий підхід і створює умови легітимації фрілософії теїзму.

Теоретико-методологічний аналіз концепції «соціальна діяльність - духовність - культура» представлений у працях таких вітчизняних науковців як А. Єрмоленко, М. Попович, Н. Хамітов тощо, наприклад, С. Кримський зазначає, що «діяльність людини має матеріальний, предметний та потенційний аспекти. Перший з них характеризує предметно-змінюючу активність, здатність людини бути причиною змін у світі, а другий - розкривається певними потенціалами. До них належать: потенціал інтенціональності, шо визначається мірою залученості до духу та самодіяльності; потенціал екстенсивності, що міряється простором чи сферою випробування різних можливостей дії та потенціал орієнтації, що характеризується цілепокладанням, смисловизначенністю взагалі» [3, с. 49].

Виділення недосліджених частин загальної проблеми. Аналіз комплексної проблеми вирішення феномену формування ідеальної типології соціальної дії за допомогою духовнопрактичного потенціалу філософського теїзму здійснюється у науковій літературі вперше.

Постановка завдання. Дослідити феномен соціальної дії в конструкціях фрілософії теїзму.

Виклад основного матеріалу. Звертаючись до загальної теорії Макса Вебера, маємо відзначити два таких базових поняття як «соціальна дія» та «раціоналізація». Причому «соціальна дія» по теорії М. Вебера відрізняється від міркувань інших дослідників тим, що будьяка дія повинна мати дві обов'язкові риси для статусу «соціальної дії». Перша умова для перетворення звичайної дії на соціальну є орієнтація на сприйняття її з боку інших людей, наприклад, дії релігійного характеру не $€$ соціальними, якщо вони не виходять за межи споглядання або проголошеної наодинці молитви тощо. Другою умовою стає необхідність наділення самої дії смислом для того, хто її здійснює, тобто з'ясування мотиваційної складової. Зацікавленість Вебером теорією соціальної дії в кінці XIX - початку XX ст. є абсолютно виправданою у зв'язку з тим, що на той момент спостерігається бурхливе зростання наукових досліджень у сфері економічних пошуків і розробки антропологів стосовно формування культурних принципів розвитку на прикладі первісних суспільств. Як бачимо, в соціологічні теорії починають додаватися розвідки соціальних антропологів і, відповідно, розширюється термінологія соціальних інститутів, а також ідеї економістів стосовно дослідження діяльності окремого індивіда, його мотивів у підприємницькій діяльності, стимулювання праці тощо. Причому концепція класової нерівності не займає в його теорії центрального положення, також можемо додати думку й Дж. Дьюї: «гіпотеза, яка допускає те, що суспільства створюють визнання певних - масштабних, довготривалих, опосередкованих - наслідків тих або інших дій, дозволяє пояснити відносність держав, у той час як теорії, визначаючи державу в термінах специфрічної причинної залежності, вважають абсолютність поняття держави, а це не відповідає фактам. Спроби відшукати за допомогою «компаративістських методів» дещо спільне між античними та сучасними, західними і східними країнами, призводить лише до пустої трати сил. Єдино постійна функція - регулювання і забезпечення інтересів, які фрормуються внаслідок складного, опосередкованого розширення та розповсюдження сумісної діяльності» [4, с. 37], тому вже сьогодні відбувається процедура заміщення поняття абстрактного індивіда на концепт «соціального суб'єкта діяльності». Такий суб'єкт є включеним у розгалужену мережу суспільних відносин і проводить активну політику з її фрормування на засадах історично сформованого духовно-ціннісного потенціалу. 
У свою чергу, людина у концептуальних підходах філософьського теїзму єдина в світі істота яка об'єднує собою тварну природу та буття Абсолюту. Ідея триєдиної структури людини у християнський теології набуває в системі соціальних відносин свого діяльнісно-практичного значення. Відбувається концептуалізація цілісного образу людини, в якому дух, як структурний компонент, виконує домінантну роль у таких побудовах. Ціннісно-символічний зміст фрілософрського теїзму також проявляється і на лінгвістичному рівні, він дозволяє конструювати не лише терміни, а бере участь у формуванні категорій як такого способу поняттєвого узагальнення досвіду, який уможливлює опис світу загалом, водночас формуючи відчуття приналежності до такого способу бачення дійсності кожного члена групи, адже «категорії - це, головним чином, колективні уявлення» [5, с. 192]. Лише описаний за їх допомогою світ стає «своїм» світом відображаючи спосіб життя спільноти. Водночас сформовані в межах релігії поняття стосуються і регламентації життя суспільства, перетворюючи його не в сукупність індивідів, що проживають на певній території та пов'язані спільними інтересами, тобто поєднані ситуативно, а генерує ціннісне підґрунтя співжиття, призводячи тим самим до формування єдиної моральної спільноти зі своїми ціннісними пріоритетами. Такий підхід підтримує тезу про те, що релігія завершує оформлення розуміння взаємодії людини і світу, при цьому розділяючи світ як природне довкілля, так і комунікаційний світ між людьми, який відбудовується завдяки фуннкціонуванню соціальної дії: «Власне, в такому разі відбувається закладання фундаменту культури як такого унікального явища, що притаманне саме цій спільноті і вирізняє ї̈ 3-поміж інших. Вона ґрунтується на ціннісно-метафоричному апараті релігії, здійснюючи своєрідну надбудову у формі інших культурних цінностей, що безпосередньо не стосуються першої, однак зазнають легітимаційного їх впливу. У цьому сенсі можна говорити про зв'язок релігії та особливості естетичних уявлень, що домінують у певному суспільстві, специфріки ведення економічної діяльності, здійснення політичного врядування тощо» [6, с. 167].

Т. Парсонс також визнає релігію базовим чинником, який закладає основні ціннісні орієнтації функціонування суспільства. 3 нашої точки зору, ціннісні конструкції філософрського теїзму мають принципове значення у комунікаційних процесах різного роду суспільних перетворень: «символічних значень..., що формують людську поведінку» [7, с. 691], - тобто здійснюють вплив на систему дій у виборі певних альтернатив. Людина у реальному житті не може завжди обирати максимально раціональний шлях досягнення певних цілей, вона діє під впливом емоцій, особистих можливостей та культурно-ціннісних мотивацій. Відповідно, звертаючись до цілераціонального типу дії М. Вебера, можемо стверджувати, що він надає нам теоретикоідеальний конструкт для розуміння раціональної складової мотиваційного виміру соціальної дії. Наприклад, у системі поглядів такої конфесії християнства як протестантизм було сформовану тезу про те, що чим успішніша діяльність людини протягом життя, тим більшими є її шанси на спасіння. На основі цього з'являється «можливість виникнення етично раціональної регламентації життя пов'язаної з технічними та економічними раціоналізмом» [8, с. 59].

Отже, як бачимо, на відміну від Е. Дюркгейма, сам М. Вебер вважав, що суспільство в цілому або будь-які форми колективної взаємодії не можуть бути суб'єктами дії, таку функцію виконують тільки окремі індивіди. Тільки ті дії, які зорієнтовані на поведінку іншої особистості він називає соціальними, виділяючи при цьому такі ідеальні чотири типи: 1) афективна дія побудована основі почуттів і неусвідомлених імпульсах; 2) традиційна дія відбувається на основі звичаєвої суспільної практики; 3) цілераціональна дія, коли людина чітко визначає мету, засоби її досягнення, відповідну реакцію інших людей, причому вона супроводжується зростанням соціальної ролі науки; та 4) ціннісно-раціональна дія, яка виконується на основі свідомого сприйняття людиною морально-етичних, естетичних, релігійних цінностей у своїй поведінці [9, с. 602-643].

У свою чергу, можемо стверджувати, що ціннісна-раціональна дія завжди спрямована на досягнення тієї або іншої мети завдяки індивідуальному рівню реалізації, але в основі такого рішення знаходиться сфрормована зовнішнім впливом цінність. Людина сама обирає яку цінність підтримати та засоби досягнення своєї мети, при цьому цінність як така вже ссрормована і представлена у суспільному житті. Маючи глибоку віру у певні ідеали, людина свідомо здійснює жертовні вчинки заради інших людей. Для нашого культурного простору наявність цілих історичних періодів побудованих на ціннісно-раціональних діях великих мас людей носить характер національної традиції. Формування такого ціннісного потенціалу має свої ментальні особливості та соціально-економічні умови розвитку того або іншого народу. Застосувавши дослідження типології 
соціальної дії М. Вебера, можна здійснити аналіз механізму сталого соціального порядку завдяки ціннісно-нормативним структурам, які були сформовані в культурі суспільства.

Вітчизняний культурний простір включає в себе складну конфігурацію поєднання цінніснораціональних дій, чим саме забезпечує формування характерних рис національної традиції побудови соціальної життєдіяльності. «Діяльність, як ми бачимо, є багатоаспектною і ї̈ орієнтація здійснюється в різних категоріальних зрізах. У цілому діяльність, яка охоплює і специфріку цілереалізації, і широку галузь смислотворчості та випробування різних можливостей, ми будемо називати життєдіяльністю. Це та широка сфера, яку в її актуалізованій формі в марксистській літературі називали практикою. Термін «життєдіяльність» вживається тут лише для підкреслення не тільки актуальних, а й потенційних сфер людської присутності у світі, для констатації множинності його форм» [3, с. 51], - тому фундамент сталого соціального порядку створює конструкція певних соціальних інститутів, вона є вмонтованою у мережу соціальноекономічних і правових відносин зафріксованих в культурному просторі певного народу. Мова йде про те, що окремі елементи соціального порядку складаються 3 певних соціальних дій, кожна з яких включає в себе як соціальний норматив, що є присутнім в культурі, так і мотивацію та уявлення індивіда, який ці нормативи практично застосовує. Але культурний норматив формується століттями та зберігає свою ідентичність, відповідно, порушення соціального порядку безпосередньо пов'язане зі світоглядними та мотиваційними чинниками діючої людини.

Висновки. Формування такого ціннісного потенціалу має свої ментальні особливості та соціально-економічні умови розвитку того або іншого народу. У свою чергу, фрілософський теїзм має величезне культурологічне та соціальне значення, саме він завдяки диференційної сукупності своїх фрорм завжди здійснює функцію посередника між релігійними засадами та соціокультурним середовищем. Ідеї фрілософського теїзму завжди носять характер філософської концептуалізації, яка здійснюється на засадах певної релігійно-культурної традиції та має конкретний історико-семантичний вимір. Філософський теїзм завдяки можливостям формування ідеальної типології соціальної дії забезпечує процес унікального поєднання духовного потенціалу християнської традиції та сучасної соціально-правової структури базових європейських цінностей для забезпечення принципово-стабільних засад функціонування соціального порядку. Європейське розуміння індивідуальної свободи набуває сьогодні якісно нової ознаки, яка проявляє себе у процесі постійного засвоєння морально-правових норм сумісного існування, що забезпечує практичне розуміння відмінностей між свободою i свавіллям. Запорукою сучасної самореалізації індивіда виступає наявність та можливості прояву його внутрішньої свободи, яка уособлює собою автономне буття особистості, що передбачає розумне ставлення людини до зовнішніх впливів і збереження себе як цілісності.

Отже, суспільно-історична динаміка фрілософської концептуалізації духовно-особистісної дійсності певного соціального життя формує свого роду ідеальну типологію соціальної дії, а дар свободи, який надається кожній людини реалізується через його участь у суспільному житті та громадських справах, тільки таким шляхом можна забезпечити та зберегти сталий соціальний порядок.

\section{Література}

1. Штомпка, П. Социология социальных изменений / П. Штомпка ; пер. с англ., под ред. В.А. Ядова. - М. : Аспект Пресc, 1996. -416 c.

2. Парсонс, Т. О структуре социального действия / Т. Парсонс. - М. : Академический проект, 2000. - 880 с.

3. Кримський, С. Б. Запити філософфських смислів / С. Б. Кримський. - К. : Вид. ПАРАПАН, 2003. - 240 с.

4. Дьюи Дж. Общество и его проблемы / Дж. Дьюи. - М. : Идея-пресс, 2002. - 160 с.

5. Дюркгейм, Э. Элементарные формы религиозной жизни. Тотемистическая система в Австралии / Э Дюркгейм // Мистика. Религия. Наука. Класики мирового религоведения. Антология. - М. : Канон Плюс, 1998. - С. 174-231.

6. Попович, М.Д.Соціально-філософський аналіз антропологічного виміру культури: монографія / М. Попович. Камянець-Подільський : ФОП Сисин Я. І., 2013. - 308 с.

7. Кребер, А. Понятие культуры и социальной системы / А. Кребер, Т. Парсонс // Парсонс Т. О социальных системах / Т. Парсонс; [под ред. В. Ф. Чесноковой и С. А. Белановского]. - М. : Академический Проект, 2002. - C. 687-692.

8. Вебер, М. Хозяйственная этика мировых религий / М. Вебер // Вебер М. Избранное. Образ общества. - М. : Юрист, 1994. - С. 43-77.

9. Вебер, М. Основные социологические понятия / М. Вебер // Вебер М. Избранные произведения. - М. : Прогресc, 1990. - С. 602-643. 


\section{References}

1. Shtompka, P. (1996). Sotsiologiya sotsialnykh izmeneniy [Sociology of social change]. Moscow: Aspekt Press [in Russian].

2. Parsons, T. (2000). O strukture sotsialnogo deystviya [About the structure of social action]. Moscow: Akademicheskiy proekt [in Russian].

3. Krymskyi, S. B. (2003). Zapyty filosofskykh smysliv [Requests of philosophical meanings]. Kyiv: Vid. PARAPAN [in Ukrainian].

4. Dewey, J. (2002). Obshchestvo i ego problemy [Society and its problems]. Moscow: Ideya-press [in Russian].

5. Durkheim, E. (1998). Elementarnye formy religioznoy zhizni. Totemisticheskaya sistema v Avstralii [Elementary forms of religious life. Totemistic system in Australia]. Mistika. Religiya. Nauka. Klasiki mirovogo religovedeniya. Antologiya - Mysticism. Religion. The science. Classics of world religious studies. Anthology. (pp. 174-231). Moscow: Kanon Plyus [in Russian].

6. Popovych, M. D. (2013). Sotsialno-filosofskyi analiz antropolohichnoho vymiru kultury [Socio-philosophical analysis of the anthropological dimension of culture]. Kamianets-Podilskyi: FOP Sysyn Ya. I. [in Ukrainian].

7. Parsons, T. (2002). Ponyatie kultury i sotsialnoy sistemy [Concept of culture and social system]. O sotsialnykh sistemakh-On social systems. (pp. 687-692). Moscow: Akademicheskiy proekt [in Russian].

8. Weber, M. (1994). Khozyaystvennaya etika mirovykh religiy [Economic ethics of world religions]. Veber M. Izbrannoe. Obraz obshchestva - Weber M. Favorites. The image of society. (pp. 43-77). Moscow: Yurist [in Russian].

9. Weber, M. (1990). Osnovnye sotsiologicheskie ponyatiya [Basic sociological concepts]. Veber $M$. Izbrannye proizvedeniya - Weber M. Selected works. (pp. 602-643). Moscow: Progress [in Russian].

Надійшла 22.11.2019

Бібліографічний опис для цитування :

Вихованець, 3. С. Феномен соціальної дії в конструкціях фрілософії теїзму / 3. С. Вихованець // Проблеми соціальної роботи: філософрія, психологія, соціологія. - 2019 - № 2 (14) - С. 7-12. 